\title{
RANCANG BANGUN KONVERSI ENERGI SURYA MENJADI ENERGI LISTRIK DENGAN MODEL ELEVATED SOLAR TOWER
}

\author{
Oleh:
}

\begin{abstract}
Zainul Hasan ${ }^{1}$, Erika Rani
ABSTRAK: Konversi energi adalah proses perubahan energi. Alat konversi energi pada penelitian ini memanfaatkan energi matahari untuk diubah menjadi energi kinetik melalui media kolektor. Unit kolektor sebagai media penangkap radiasi matahari terdiri dari beberapa bagian. Diantaranya adalah: Kaca penutup, Penyerap panas (Absorber), dan Kerangka penyangga.

Dalam penelitian rancang bangun konversi energi surya menjadi energi listrik dengan metode elevated solar tower terdapat 2 tahap penelitian. Yang pertama adalah tahap perancangan alat. Serta tahap yang kedua adalah tahap eksperimen (pengujian) alat. Eksperimen ini dilakukan dengan tujuan untuk mengetahui efisiensi kolektor serta untuk mengetahui efisiensi sistem alat konversi energi tersebut. Pengujian alat konversi tersebut dilakukan pada tanggal 27 oktober 2011 sampai dengan tanggal 5 November 2011, dengan 2 tahapan percobaan. Yang pertama adalah penelitian dilakukan di dalam ruangan dan yang kedua adalah penelitian dilakukan di luar ruangan. Dalam penelitian ini terdapat beberapa variasi intensitas cahaya yang digunakan. Intensitas yang digunakan adalah 31.600Lux, 43 300 Lux, and 56,000 Lux.

Dari hasil penelitian tersebut menunjukkan bahwa efisiensi panas pada kolektor tidak konstan. Efisiensi kolektor tertinggi mencapai $83,92 \%$ sedangkan terendah mencapai $22,55 \%$ dengan rata-rata sebesar 57\%. Dan efisiensi sistem dari alat konversi tersebut tertinggi mencapai $0,01 \%$ sedangkan terendah mencapai $0,0022 \%$ dengan rata-rata efisiensi sebesar 0,0053\%. Adapun daya listrik yang dihasilkan mencapai 72,469
\end{abstract}

Kata Kunci : Konversi Energi, Elevated Solar Tower, Efisiensi Kolektor

\section{PENDAHULUAN}

Kebutuhan energi di dunia saat ini semakin meningkat seiring dengan pertambahan penduduk, pertumbuhan ekonomi dan pola konsumsi energi itu sendiri yang senantiasa meningkat. Salah satu energi yang sering dipakai oleh masyarakat sebagai kebutuhan sehari-hari adalah energi listrik. Energi listrik merupakan kebutuhan mutlak bagi aktivitas keseharian setiap masyarakat, terutama untuk kebutuhan rumah tangga, sektor usaha dan industri.

Bila ditinjau dari sumber pengadaan energi saat ini. Sumber energi dunia masih sangat bergantung pada energi fosil, yang tidak dapat diperbarui lagi dengan jumlah sangat terbatas dan semakin lama semakin menipis serta pada suatu saat akan habis. Menurut Christ Lewis dalam bukunya yang berjudul Biological Fuels memperkirakan bahwa gas alam akan habis pada tahun 2047, minyak bumi pada tahun 2080, dan batu bara pada tahun 2180. Hal ini disebabkan karena energi fosil dieksplorasi secara besar-besaran dan tidak sebanding dengan waktu pembentukan energi fosil tersebut.

1,2 Jurusan Fisika Fakultas Sains dan Teknologi UIN Maliki Malang 
Dengan adanya fakta tersebut maka upaya-upaya pencarian sumber energi alternatif semakin banyak dilakukan. Dalam upaya pencarian sumber energi alternatif baru sebaiknya memenuhi syarat yaitu menghasilkan jumlah energi yang cukup besar, biaya ekonomis dan tidak berdampak negatif terhadap lingkungan. Berdasarkan pertimbangan tersebut, pencarian tersebut diarahkan pada pemanfaatan energi matahari. Untuk dapat memanfaatkan energi radiasi matahari dalam menghasilkan energi listrik, digunakan suatu perangkat yang dapat mengumpulkan energi radiasi matahari yang sampai ke permukaan bumi dan mengubahnya menjadi energi kalor yang berguna. Perangkat ini disebut dengan kolektor surya.

Oleh karena itu, penulis dalam hal ini ingin mencoba untuk mendesain rancangan alat tersebut dengan mengambil judul Rancang Bangun Konversi Energi Surya Menjadi Energi Listrik Dengan Menggunakan Model Elevated Solar Tower.

\section{KAJIAN TEORI}

Matahari adalah bintang yang paling dekat dengan bumi, sehingga penelitian tentang bintang ini lebih mudah dari pada bintang lainnya. Matahari memiliki jarak 150 juta kilometer dari bumi, dan dia menyediakan energi yang dibutuhkan oleh kehidupan di bumi ini secara terus-menerus (Mulyono, 2007: 47). Energi yang dibebaskan oleh matahari setiap detinya menurut perhitungan para ahli, adalah ekuivalen dengan konversi massa hidrogen yang besarnya adalah $4,2 \times 10^{6}$ ton/detik, yang ekuivalen dengan $1,2 \times 10^{16} \mathrm{KW}$ (Daryanto, 2007: 72).

Energi yang diradiasikan akibat transformasi hidrogen menjadi helium yang kemudian menghasilkan energi

$$
4_{1} H_{1} \rightarrow 2 H e^{4}+2 e^{+}+\text {energi }
$$

Sebagian energi tersebut di transmisikan ke bumi dengan cara radiasi gelombang elektromagnetik. Radiasi menjalar dengan kecepatan cahaya $\left(3 \times 10^{8} \mathrm{~m} / \mathrm{s}\right)$ dalam bentuk gelombang yang mempunyai panjang gelombang yang berbeda-beda. Peristiwa ini akan berhenti jika hidrogen dalam reaksi inti habis (Daryanto, 2007: 72).

Untuk menghitung komponen langsung dari pemasukan radiasi surya pada sebuah permukaan miring dari data radiasi pada sebuah permukaan horisontal, posisi matahari pada tiap saat harus diketahui (Arismunandar, 1985). Radiasi matahari yang diterima oleh permukaan bidang miring dengan sudut kemiringan $\beta, H_{t}$ bisa dihitung sebagai (Cao. 2011: 2362):

$$
H_{t}=H_{t, b}+H_{t, d}
$$

sedangkan, radiasi matahari pada permukaan horizontal (Cao. 2011: 2362):

$$
H_{t}=H_{b}+H_{d}
$$


dimana $\mathrm{H}$ adalah radiasi melambung total pada permukaan horizontal, $H_{t, b}$ adalah radiasi matahari bare, $H_{t, d}$ adalah radiasi matahari menyebar dan $H_{t, r}$ adalah radiasi matahari yang dipantulkan. Mereka bisa dihitung oleh tiga persamaan berikut ini

$$
\begin{aligned}
& H_{t, b}=H_{b} R_{b} \ldots . \\
& H_{t, d}=H_{d} R_{d} \ldots \\
& H_{t, r}=r e f H R_{r}
\end{aligned}
$$

dimana $H_{b}$ adalah radiasi bare total pada permukaan horisontal, $H_{d}$ adalah radiasi tersebar total pada permukaan horizontal. ref adalah reflektansi tanah. Menurut literatur Muneer itu, ref adalah 0,25. Dan $R_{b}, R_{d}$, dan $R_{r}$ adalah koefisien. Semua dapat dihitung dalam persamaan berikut (Duffie, 2005: 104):

$$
\begin{aligned}
& R_{b}=\frac{\cos (\emptyset+\beta) \cos \delta \sin \omega_{s}+(\pi / 180) \omega_{s} \sin (\emptyset+\beta) \sin \delta}{\cos \emptyset \cos \delta \sin \omega_{s}+(\pi / 180) \omega_{s} \sin \emptyset \sin \delta} . .(6) \\
& R_{d}=\frac{H_{b}}{H_{0}} R_{b}+\frac{1}{2}\left(1-\frac{H_{b}}{H_{0}}\right)(1+\cos \beta) \\
& R_{r}=\frac{1+\cos \beta}{2}
\end{aligned}
$$

dimana $\delta$ adalah sudut deklinasi, $\varnothing$ sudut garis lintang, $\beta$ adalah sudut kemiringan kolektor dan $\omega$ adalah Sudut Jam

Radiasi matahari total pada permukaan miring akhirnya dapat dinyatakan sebagai (Cao. 2011: 2362):

$$
H_{t}=H_{b} R_{b}+H_{d}\left[\frac{H_{b}}{H_{0}} R_{b}+\frac{1}{2}\left(1-\frac{H_{b}}{H_{0}}\right)(1+\cos \beta)\right]+\frac{1}{2} r e f H(1-\cos \beta)
$$

Sinar matahari melalui kaca mentransmisikan dan memanaskan udara dan panas kekurangan lapisan bawah kaca. Jadi $H_{t}$ insiden dapat dibagi menjadi tiga bagian: radiasi yang dipantulkan $H_{r e f}$, radiasi mentransmisikan melalui $H_{1}$ kaca dan radiasi diserap oleh $\mathrm{H}_{2}$ kaca

$$
H_{t}=H_{\text {ref }}+H_{1}+H_{2}
$$

$H_{r e f}$ bisa dihitung dengan Persamaan 5. Dan $H_{1}$ dan $H_{2}$ bisa dihitung oleh persamaan berikutnya

$$
\begin{aligned}
& H_{1}=H_{b} R_{b}(\tau \alpha)_{b}+H_{b}\left[\frac{H_{b}}{H_{0}} R_{b}+\frac{1}{2}\left(1-\frac{H_{b}}{H_{0}}\right)(1+\cos \beta)\right](\tau \alpha)_{d} \ldots \ldots \ldots \ldots . . .(11) \\
& H_{2}=H_{b} R_{b}(\alpha)_{b}+H_{d}\left[\frac{H_{b}}{H_{0}} R_{b}+\frac{1}{2}\left(1-\frac{H_{b}}{H_{0}}\right)(1+\cos \beta)\right](\alpha)_{d}+\frac{1}{2} \rho H(1- \\
& \cos \beta) \alpha_{r} \ldots \ldots \ldots \ldots \ldots \ldots \ldots \ldots \ldots \ldots \ldots \ldots
\end{aligned}
$$


Dimana:

$\alpha$ adalah tingkat penyerapan

$\tau$ adalah rasio transmitansi dari penutup kaca

$(\tau \alpha)$ adalah tingkat penyerapan selama proses transmisi, yang terkait dengan materi

(Cao. 2011: 2362-2363).

Bila dua benda atau lebih terjadi kontak termal maka akan terjadi aliran kalor dari benda yang bertemperatur lebih tinggi ke benda yang bertemperatur lebih rendah, hingga tercapainya kesetimbangan termal. Proses perpindahan panas ini berlangsung dalam 3 mekanisme, yaitu :

1. konduksi,

2. konveksi

3. dan radiasi.

Definisi dari efisiensi termal kolektor surya yaitu perbandingan antara energi yang digunakan dengan jumlah energi surya yang diterima pada waktu tertentu. Parameterparameter yang menentukan efisiensi termal adalah $\mathrm{H}_{\mathrm{t}}$ intensitas radiasi yang datang ke permukaan kolektor panas surya $\left(\mathrm{W} / \mathrm{m}^{2}\right), \mathrm{A}_{\mathrm{p}}$ luas kolektor panas surya $\left(\mathrm{m}^{2}\right)$, Sehingga efisiensi termal kolektor surya dapat dinyatakan dengan persamaan (Cao. 2011: 2362):

$$
\eta=\frac{Q}{H_{t} A_{k o l l}}
$$

dimana

$$
\begin{aligned}
& Q=\dot{m} C_{p}\left(T_{0}-T_{a}\right) \\
& \dot{m}=\rho A_{c h i} v_{f}
\end{aligned}
$$

Chimney merupakan bagian mesin dari sistem elevated solar tower. Tekanan yang dihasilakn oleh chimney digunakan dalam tiga bagian: rugi-rugi yang hilang dalam kolektor dan chimney $\Delta \mathrm{P}_{\mathrm{f}}$, energy kinetic yang hilang pada keluaran chimney $\Delta \mathrm{P}_{\mathrm{KE}}$, dan energi kinetik yang digunakan untuk menghentikan turbin $\Delta \mathrm{P}_{\mathrm{t}}$.

$$
\Delta P_{t o t}=\Delta P_{f}+\Delta P_{K E}+\Delta P_{t}
$$

dimana $\Delta P_{f}$ dan $\Delta P_{K E}$ dapat dihitung menurut prinsip hidrodinamik sebagai:

$$
\begin{aligned}
& \Delta \mathrm{P}_{\mathrm{f}}=\mathrm{f} \frac{\mathrm{L}_{\text {th }}}{\mathrm{D}} \frac{1}{2} \rho_{\mathrm{avr}} \mathrm{v}^{2}{ }_{\mathrm{avr}} \\
& \Delta \mathrm{P}_{\mathrm{KE}}=\frac{1}{2} \rho_{\text {chi }} \mathrm{v}^{2} \text { chi }
\end{aligned}
$$

dimana $\mathrm{L}_{\text {th }}$ adalah panjang dari kolektor, $\mathrm{f}$ adalah rugi-rugi yang hilang, $\rho_{\mathrm{avr}}$ adalah kerapatan aliran udara rata-rata, $v^{2}$ avr adalah kecepatan udara rata-rata, $v_{\text {chi }}$ adalah 
kecepatan aliran udara yang keluar dari chimney, dan $\rho_{\text {chi }}$ adalah kerapatan aliran udara pada keluaran chimney.

Rugi-rugi yang hilang dalam kolektor diabaikan dalam kajian ini, persaman 30 dapat ditulis sebagai:

$$
\Delta P_{t o t}=\Delta P_{K E}+\Delta P_{t}
$$

Tekanan meningkat karena kerapatan udara berbeda antara inlet dan outlet dalam chimney dapat dihitung sebagai berikut:

$$
\Delta \mathrm{P}=\int_{\text {inlet }}^{\text {outlet }} \mathrm{g}\left(\rho_{\mathrm{a}}-\rho(\mathrm{z})\right)
$$

dimana $\rho_{\mathrm{a}}$ adalah kerapatan udara lingkungan.

Untuk chimney vertikal adiabatik dengan menggabungkan persamaan 20, sehingga menghasilkan persamaan

$$
\Delta \mathrm{P}_{\text {tot }}=\left(\rho_{\mathrm{a}}-\rho_{0}\right) \mathrm{g} \mathrm{H}_{\text {chi }}
$$

Kita asumsikan variasi kerapatan udara adalah linier antara kolektor inlet dan outlet. Menurut teori fisika dan matematika, tekanan yang dihasilkan oleh kolektor dan chimney adalah

$$
\begin{aligned}
& \Delta \mathrm{P}_{\text {col }}=\frac{\left(\rho_{\mathrm{a}}-\rho_{\mathrm{f}}\right)}{2} \mathrm{~g} \mathrm{H}_{\mathrm{col}} \ldots \ldots \\
& \Delta \mathrm{P}_{\mathrm{chi}}=\left(\rho_{0}-\rho_{\mathrm{f}}\right) \mathrm{g} \mathrm{H}_{\mathrm{chi}}
\end{aligned}
$$

dimana $\rho_{\mathrm{f}}$ adalah kerapatan udara rata-rata dalam kolektor, $\mathrm{H}_{\text {chi }}$ adalah ketinggian chimney, $\Delta \mathrm{P}_{\text {chi }}$ dan $\Delta \mathrm{P}_{\text {col }}$ adalah tekanan yang dihasilkan kolektor dan chimneay secara terpisah.

Sehingga tekanan total dari gaya apung dapat dituliskan sebagai:

$$
\begin{aligned}
& \Delta P_{t o t}=\Delta P_{K E}+\Delta P_{t}=\frac{1}{2} \rho_{c h i} v_{c h i}^{2}+\Delta P_{t}=\Delta P_{c o l}+\Delta P_{c h i}=\left(\rho_{0}-\rho_{\mathrm{f}}\right) \mathrm{g}\left(\mathrm{H}_{\mathrm{chi}}+\right. \\
& \left.\frac{1}{2} \mathrm{H}_{\mathrm{col}}\right)
\end{aligned}
$$

Daya yang dihasilkan oleh turbin, $P_{\text {ele }}$ adalah

$$
P_{\text {ele }}=\eta_{t} \Delta \mathrm{P}_{\mathrm{t}} V_{\text {out }} A_{\text {chi }}
$$

dimana $\eta_{t}$ adalah efisiensi turbin, $V_{\text {out }}$ adalah kecepatan aliran udara pada keluaran kolektor surya.

Efisiensi sistem dari alat konversi energi surya dapat dijabarkan sebagai:

$$
\eta_{\text {sistem }}=\frac{P_{\text {ele }}}{H_{t} A_{\text {coll }}}
$$




\section{METODE PENELITIAN}

Rancang bangun alat konversi energi pada penelitian ini memanfaatkan energi cahaya untuk diubah menjadi energi kinetik yang merupakan kecepatan angin melalui media kolektor. Unit kolektor sebagai media penangkap radiasi matahari terdiri dari beberapa bagian, yaitu: Penutup transparan, Penyerap panas (Absorber), isolasi, Kerangka penyangga. Adapun bahan yang digunakan dalam pembuatan alat tersebut diantaranya adalah plat aluminium, kaca transparan, bahan beton (pasir, semen, dan kerikil, kawat besi), cat hitam, serta pipa paralon. Sedangkan dalam penelitian ini juga dibutuhkan beberapa alat yang digunakan dalam pengujian alat, diantaranya adalah stopwatch, power supply, fluxmeter, termometer, serta anemometer.

Adapun langkah-langkah dalam pengambilan data dalam penelitian ini adalah sebagai berikut:

\section{A. Penelitian di Dalam Ruangan}

1. Pengujian alat ditempatkan didalam ruangan (laboratorium) untuk menghindari pengaruh udara luar.

2. Memasang semua alat ukur seperti termometer diletakkan pada bagian inlet (masukan udara), sistem kolektor, serta pada bagian outlet (keluaran udara). Luxmeter diletakkan diatas kolektor untuk mengukur intensitas cahaya dan Anemometer diletakkan pada pipa keluaran (solar tower) untuk mengukur kecepatan keluaran angin yang dihasilkan

3. Memasang dan menyalakan lampu halogen sebagai sumber cahaya diatas permukaan kolektor

4. Pengambilan data intensitas cahaya, perubahan temperatur serta kecepatan angin dilakukan secara periodik yaitu dilakukan setiap selang 5 menit hingga mendapatkan data sebanyak 10 data untuk setiap variasi intensitas cahaya

5. Melakukan pencatatan beberapa parameter. Diantaranya adalah:

- Intensitas cahaya radiasi

- Waktu (lama penyinaran)

- Temperatur $\left(T_{\text {in }}, T_{\text {out }}, T_{\text {koll }}\right)$

- Kecepatan udara

6. Mengulangi langkah 1 sampai dengan 5 untuk intensitas cahaya yang berbeda dengan menggeser maju mundur sumber cahaya.

\section{B. Penelitian di Luar Ruangan}

1. Pengujian alat ditempatkan di luar ruangan (laboratorium).

2. Memasang semua alat ukur seperti termometer yang diletakkan pada bagian inlet (masukan udara), sistem kolektor, serta pada bagian outlet (keluaran udara). Luxmeter diletakkan diatas kolektor untuk mengukur intensitas cahaya dan Anemometer diletakkan pada pipa keluaran (solar tower) untuk mengukur kecepatan keluaran angin yang dihasilkan 
3. Pengambilan data intensitas cahaya, perubahan temperatur serta kecepatan angin dilakukan secara periodik yaitu dilakukan setiap selang 15 menit.

4. Melakukan pencatatan beberapa parameter. Diantaranya adalah:

- Intensitas cahaya radiasi

- Waktu (lama penyinaran)

- Temperatur $\left(T_{\text {in }}, T_{\text {out }}, T_{\text {koll }}\right)$

- Kecepatan udara

5. Mengulangi langkah 1 sampai dengan 4 untuk intensitas cahaya yang berbeda dengan menggeser maju mundur sumber cahaya.

Parameter yang diukur akan dibuat dalam bentuk tabulasi data. Untuk mengetahui laju perpindahan panas secara konveksi dalam kolektor, akan dianalisis dari pengukuran temperatur temperatur udara yang masuk dan keluar dari kolektor. Serta untuk mengetahui efisiensi rancang bangun alat tersebut, di analisis dari data pengamatan perbedaan temperatur udara, kecepatan udara, serta intensitas cahaya. Adapun analisis efisiensi pada kolektor surya dan alat konversi tersebut, digunakan persamaan sebagai berikut:

$$
\begin{gathered}
\eta_{\text {kol }}=\frac{Q}{H_{t} A_{\text {koll }}} \\
\eta_{\text {sys }}=\frac{P_{\text {ele }}}{H_{t} A_{\text {koll }}}
\end{gathered}
$$

Dimana: $Q$ adalah laju perpindahan panas dalam kolektor(W)

$H_{t} A_{\text {koll }}$ adalah energi yang di terima oleh kolektor (W)

$P_{\text {ele }}$ adalah power electrical (W)

\section{HASIL DAN PEMBAHASAN}

Penelitian suatu rancang bangun alat konversi energi surya menjadi energi listrik dengan menggunakan metode elevated solar tower ini, terdapat 2 tahapan penelitian. Tahap pertama adalah tahap perancangan alat dan tahap yang kedua adalah tahap eksperimen (pengujian) alat. Berdasarkan hasil analisis dari beberapa data hasil pengamatan yaitu (temperatur masukan, temperatur keluaran, intensitas cahaya, serta kecepatan angin) sehingga dapat diketahui besar efisiensi kolektor serta efisiensi sistem dari suatu rancangan alat. Adapun efisiensi kolektor serta efisiensi sistem dari rancangan alat konversi energi tersebut dapat dilihat pada grafik di bawah ini: 


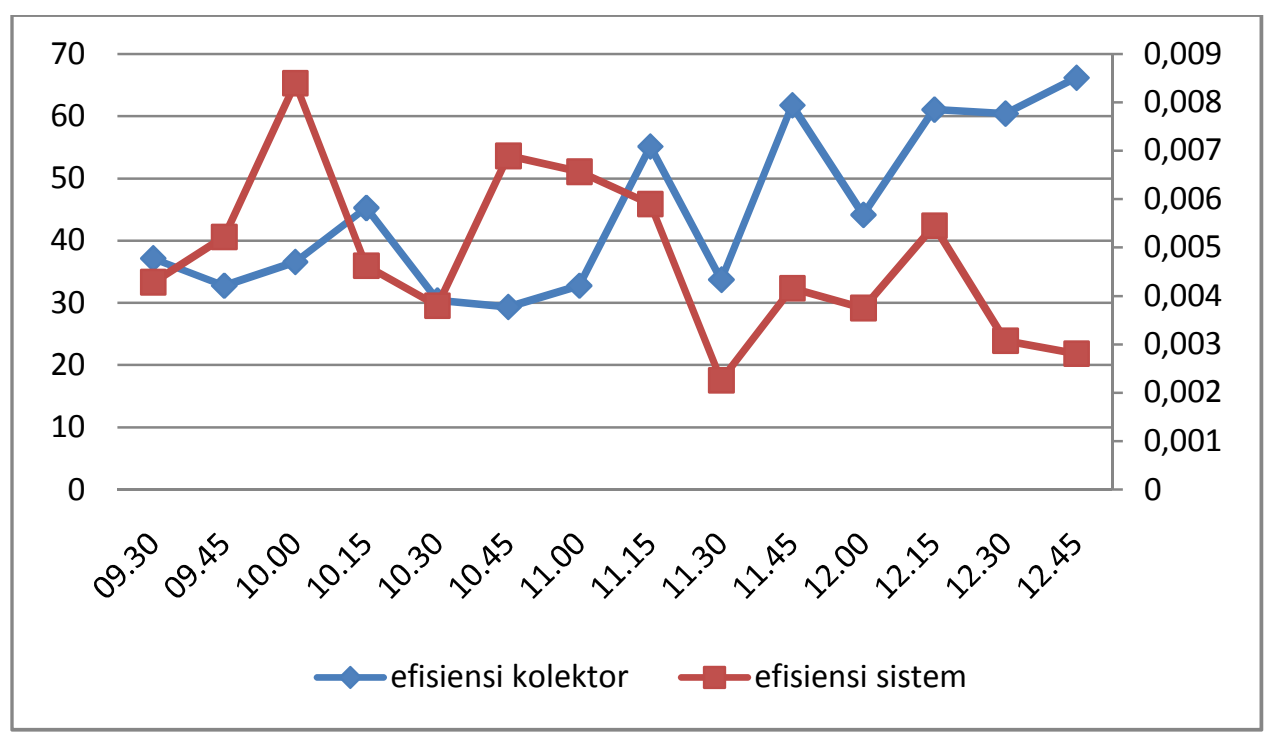

Gambar 1. Grafik efisiensi kolektor serta efisiensi sistem pada tanggal 2 November 2011

Gambar 1 di atas adalah grafik efisiensi termal kolektor surya dan efisiensi sistem pada tanggal 2 November 2011. Dari grafik tersebut di atas dapat dilihat bahwa efisiensi termal serta efisiensi sistem kolektor surya yang dihasilkan fluktuatif. Dimana terjadi suatu kenaikan dan penurunan nilai efisiensi yang cukup signifikan. Seperti yang ditunjukkan pada grafik di atas yaitu data pengamatan pada tanggal 2 November 2011, efisiensi termal pada kolektor tertinggi mencapai $66,16 \%$ yang terjadi pada jam 12.45 sedangkan nilai terendah mencapai $29,37 \%$ pada jam 10.45 dengan nilai rata-rata sebesar $44,77 \%$. Nilai efisiensi sistem dari rancang bangun alat tertinggi mencapai $0,008392 \%$ yang terjadi pada jam 10.00 sedangkan efisiensi sistem terendah mencapai $0,002257 \%$ pada jam 11.30. Adapun daya listrik yang dihasilkan oleh alat konversi tersebut dari hasil analisis matematis pada penelitian ini mencapai 51,119 mWatt sampai 14,382 mWatt dengan mengasumsikan efisiensi turbin sebesar 0,81 .

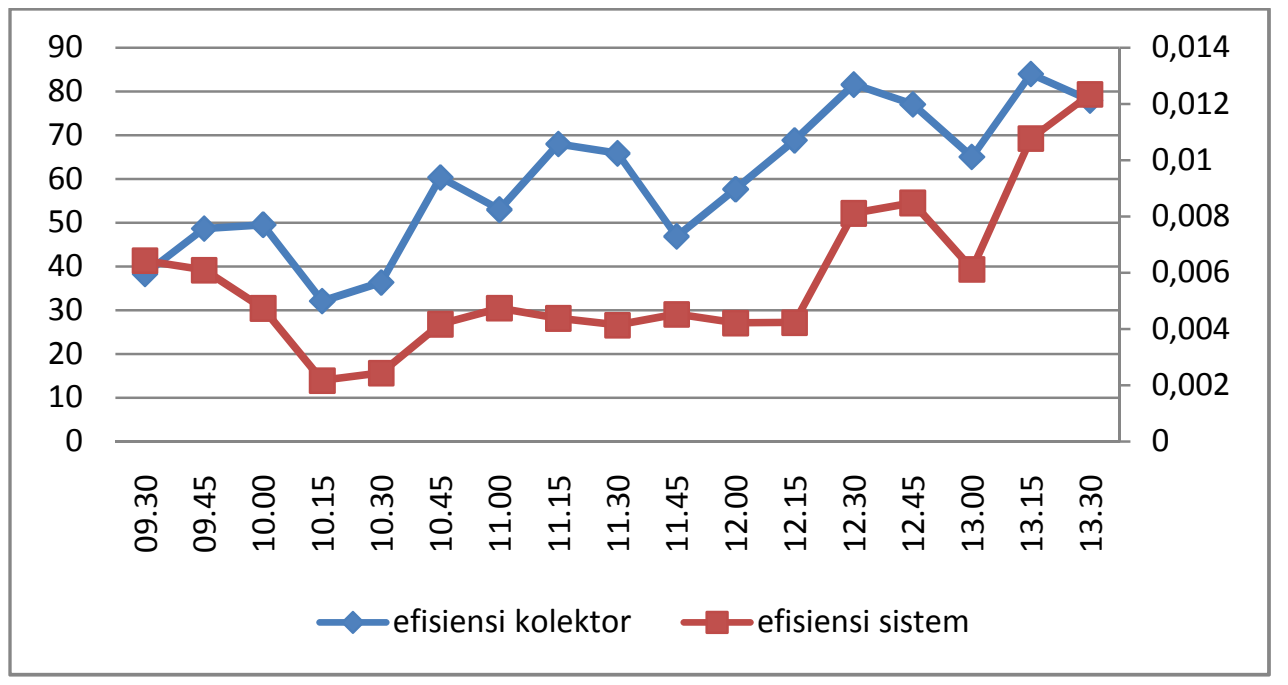

Gambar 2. Grafik efisiensi kolektor serta efisiensi sistem pada tanggal 3 November 2011 
Gambar 2 adalah grafik hasil analisis efisiensi termal kolektor surya serta efisiensi sistem pada tanggal 3 November 2011. Dari grafik di atas dapat dilihat bahwa efisiensi termal kolektor surya tertinggi mencapai $83,92 \%$ yang terjadi pada jam 13.15 sedangkan nilai terendah mencapai $32,08 \%$ pada jam 10.15 dengan nilai rata-rata sebesar 59,43\%. Nilai efisiensi sistem dari rancang bangun alat tertinggi mencapai $0,012333 \%$ yang terjadi pada jam 11.30 sedangkan efisiensi sistem terendah mencapai $0,002168 \%$ pada jam 10.15 . Adapun daya listrik yang dihasilkan oleh alat konversi energi tersebut dari hasil analisis matematis pada penelitian ini mencapai nilai tertinggi pada 53,739 mWatt sedangkan daya terendah yang dihasilkan oleh alat mencapai 12,54 mWatt dengan mengasumsikan efisiensi turbin sebesar 0,81 .

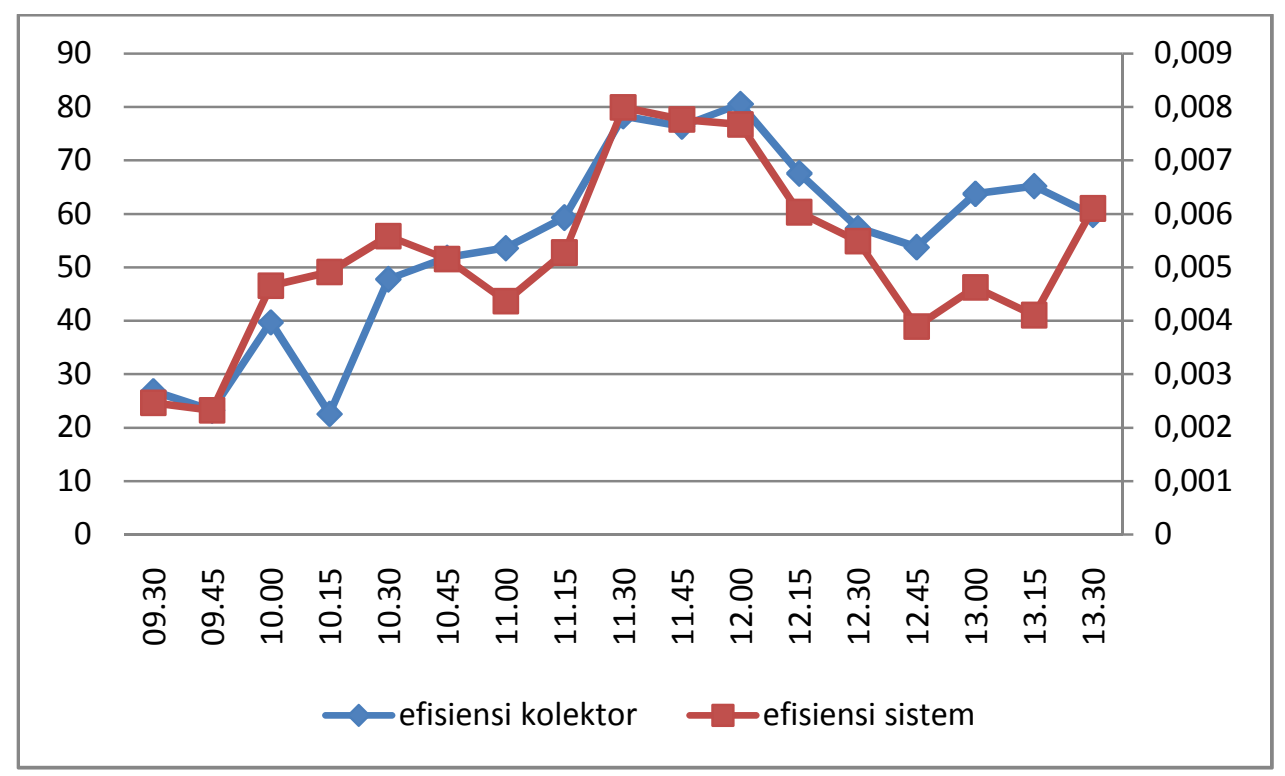

Gambar 3. Grafik efisiensi kolektor serta efisiensi sistem pada tanggal 5 November 2011

Gambar 3 tersebut di atas adalah grafik data hasil analisis efisiensi termal kolektor dan efisiensi sistem alat konversi pada tanggal 5 November 2011. Dari grafik di atas dapat dilihat bahwa efisiensi termal dari kolektor surya tertinggi mencapai $83,92 \%$ yang terjadi pada jam 13.15 sedangkan nilai terendah mencapai 32,08\% pada jam 10.15 dengan nilai rata-rata sebesar $59,43 \%$. Nilai efisiensi sistem dari rancang bangun alat tertinggi mencapai 0,007991\% yang terjadi pada jam 11.30 sedangkan efisiensi sistem terendah mencapai $0,002318 \%$ pada jam 09.45 dengan nilai rata-rata sebesar 0,0673 . Adapun daya listrik yang dihasilkan oleh alat konversi energi tersebut dari hasil analisis matematis pada penelitian ini mencapai nilai tertinggi pada 72,469 mWatt sedangkan daya listrik terendah yang dihasilkan oleh alat mencapai 13,042 mWatt dengan mengasumsikan efisiensi turbin sebesar 0,81 .

Berdasarkan ketiga grafik tersebut di atas jelaslah bahwa efisiensi sistem dan efisiensi termal kolektor yang dihasilkan oleh rancangan alat konversi tersebut memiliki kurva yang memiliki kecenderungan yang serupa. Efisiensi termal kolektor serta efisiensi 
sistem rancangan alat konversi dari beberapa penelitian mengalami ketidakteraturan. Dimana nilai efisiensi termal kolektor surya dan efisiensi sistem alat yang dihasilkan sangat fluktuatuf. Hal ini dapat dilihat pada grafik-grafik tersebut di atas, bahwa efisiensi kolektor mengalami kenaikan dan penurunan yang cukup signifikan. Kenaikan dan penurunan nilai efisiensi kolektor tersebut dipengaruhi oleh intensitas cahaya matahari yang diterima oleh kolektor pada rancangan alat tersebut. Dimana dari data hasil pengamatan intensitas cahaya matahari yang dipancarkan ke permukaan bumi selama pengamatan juga fluktuatif. Seperti yang diketahui bahwa intensitas matahari yang diterima oleh kolektor akan mempengaruhi energi termal dari kolektor, baik temperatur masukan, keluaran, maupun temperatur plat yang dihasilkan, sehingga dalam penelitian tersebut energi termal yang dihasilkan oleh kolektor juga mengalami kenaikan dan penurunan yang sangat signifikan.

Dari hasil analisis ketiga grafik tersebut di atas, dapat dijelaskan bahwa penurunan efisiensi termal kolektor surya disebabkan karena banyak kalor yang hilang (dilepaskan) ke lingkungan baik secara konveksi maupun konduksi. Perpindahan kalor dari permukaan absorber ke permukaan kaca bagian dalam dan pada permukaan luar kaca ke lingkungan terjadi secara konveksi alami, sedangkan perpindahan kalor melalui permukaan bawah kaca ke permukaan atas kaca terjadi secara konduksi, sehingga kerugian kalor pada bagian atas kolektor hanya terjadi secara konveksi dan konduksi. Hal ini sesuai dengan pernyataan hukum II termodinamika bahwa "Tidak ada proses yang dapat berlangsung terus menerus dengan menyerap kalor dan mengkonversikan seluruh kalor yang diserap tersebut menjadi kerja tanpa hasil samping" (Purwanto, 2007: 18). Konversi kalor menjadi kerja pada alat ini terdapat sebagian energi yang hilang karena terjadi perpindahan kalor secara konveksi dan konduksi dari kaca ke lingkungan.

Energi yang hilang pada kolektor terjadi saat kondisi intensitas cahaya fluktuatif, yaitu ketika intensitas cahaya turun maka laju kalor yang terperangkap kolektor sebagian keluar secara konduksi dari permukaan bawah kaca kepermukaan atas kaca dan selanjutnya keluar melalui konveksi melalui angin. Hal ini terjadi kerena perbedaan temperatur antara kolektor dengan lingkungan. Dimana kaca menerima radiasi dari matahari dan radiasi pantul plat, sehingga semakin tinggi temperatur plat maka semakin besar pula radiasi balik yang dipantulkan ke cover, akibatnya temperatur cover semakin tinggi, dengan semakin besar temperatur cover maka akan semakin besar kehilangan panas dari sistem ke lingkungan.

Dari hasil penelitian tersebut, sehingga dapat dikatakan bahwa hasil analisis efisiensi kolektor dari kolektor surya dalam penelitian ini bukanlah suatu konstanta melainkan sebuah karakteristik dengan variabel yang bergantung dari intensitas matahari, serta perbedaan temperatur (masukan dan keluaran) kolektor (Burhanuddin, 2005). Dimana untuk memperoleh nilai efisiensi yang tinggi, intensitas matahari yang diterima oleh kolektor tidak fluktuatif dan permukaan kolektor tegaklurus dengan posisi matahari, dan perbedaan temperatur masukan dan keluaran maksimum. Perbedaan temperatur akan maksimum jika permukaan kolektor tegaklurus dengan posisi matahari. Selain itu, faktor yang mempengaruhi efisiensi solar tower adalah updraft force, yakni gaya apung yang 
menyebabkan udara panas naik ke atas. Semakin tinggi lintasan vertikal, semakin besar kecepatan gerak udara panas. Faktor ketinggian tower maupun pyramide house dalam hal ini menjadi faktor yang menentukan kelajuan udara.

\section{KESIMPULAN}

Berdasarkan hasil penelitian yang dilakukan pada rancangan alat konversi tersebut dapat disimpulkan bahwa rancangan alat tersebut memiliki nilai efisiensi yang cukup baik. Efisiensi kolektor tertinggi mencapai $83,92 \%$ sedangkan terendah mencapai $22,55 \%$ dengan rata-rata sebesar 57\%. Dan efisiensi sistem dari alat konversi tersebut tertinggi mencapai $0,01 \%$ sedangkan terendah mencapai $0,0022 \%$ dengan rata-rata efisiensi sebesar $0,0053 \%$.

\section{DAFTAR PUSTAKA}

Arismunandar, Wiranto. 1985. Teknologi Rekayasa Surya. Jakarta: PT. Pradnya paramita

Cao, Fei, dan Liejin Guo . 2011. Simulation of a sloped solar chimney power plant in Lanzhou. ELVESIER

Daryanto. 2007. Energi Masalah dan Pemanfaatannya Bagi Kehidupan Manusia. Yogyakarta: Pustaka Widyatama

Duffie, John A, dan William A. Beckam. 2006. Solar engineering of thermal processes. New Jersey: John Wiley \& Sons

Mulyono, Agus. 2007. Cahaya Diatas Cahaya Kajian Cahaya Perspektif Fisika dan Tasawuf. Malang: UIN Press 